\title{
The relationship of emotional intelligence of head room with management of the ward in hospital areas of jayapura city
}

\author{
Agussalim \\ Nursing School, Health Polytechnic of Jayapura, Indonesia.
}

Correspondence: Agussalim, Nursing School, Health Polytechnic of Jayapura, Padang Bulan Street 2, Hedam, Heram, Papua Province, Indonesia, Email Salim170878@gmail.com

Received: February 03, 2018 | Published: February 21, 2018

Copyright $\odot 2018$ Agussalim. This is an open access article distributed under the terms of the Creative Commons Attribution License, which permits unrestricted use, distribution, and reproduction in any medium, provided the original author and source are credited.

\begin{abstract}
Introduction: Head room is responsible for the achievement of the objectives set out in a ward by empowering the staff nurses under his responsibility. The success of head room depends very much on how his ability to affect staffs in nursing management. Therefore, the head of the ward expected as an effective leader and manager. The head ward as an effective manager will utilize the management process through the involvement of staff nurses under his responsibility to improve the quality of nursing services.

Purpose: The study aimed to know the relationship of emotional intelligence of head room with management of the ward in hospital areas of the city of Jayapura.

Method: The research design used in this research is descriptive correlational design by cross sectional approach where data relating to free variables and bound variables. The variables collected at the same time.

Result: The result of this research explained that there are correlational between the emotional intelligence of head room with management of the ward in several hospitals in the city of Jayapura. The correlational between emotional intelligence with the management of the ward was 0.006 , head room with the management of the ward was 0,001 , head control with the management of the ward was 0.04 , motivation of head room with the management of the ward was 0.022 , the head room the with the management of the ward was 0.002 , and at the last is correlational between social head relation with the management of the ward was 0.003 . The correlational between two research variables have lower than $\mathrm{p}$-value 0.05 as standard deviation. It means there are correlational between two variables.
\end{abstract}

Discussion: The head of the room needs to have a high emotional intelligence in their daily work.

Keywords: Emotional intelligence; The head room; The hospital; Management of the ward

\section{Introduction}

Nursing management is a process of completing jobs through a nursing staff member under its responsibility to provide professional nursing care to patients and their families. The nursing Manager is doing his task of coordination and integration of resources available through planning, organizing, direction and supervision so as to provide the most effective nursing care for patients and their families. [1,2].

The head room of the hospital is responsible for the achievement of the objectives purpose in a space unit with empowering the staff nurse under his responsibility. The success of head room depends very much on how his ability to affect staff in nursing management needs in a unit. Therefore, the head of the room expected as an effective leader and manager. The head of the room as an effective manager will utilize the management process through the involvement of staff nurses under its responsibility to improve the quality of Nursing Services [2].

Based on the interview conducted of one of the nurses in the Abepura Hospital and provincial hospital in Jayapura last $11^{\text {th }}$ of February
2015. The result showed that the head of the inpatient room did not optimally carried out his functions in accordance with the standard operational procedures. This was as cause of the needs of power in the room have not been adequate, so that the head of the room still to be directly involved in providing nursing care to patients. Another thing is still a low level of discipline of nurses and the complaints from some of the patients and families about the quality of nursing services are still lacking. In eight hours of work per shift, every nurse needs to accomplish the task to an average of one to two workloads; besides the nurse leaving the task of alternately was following the rush-hour. Still the high turnover of nurses and nursing in absence of honorary degrees is still very high. The presence of the patient and family about delayed services they received. This phenomenon illustrates the absence of a strong foundation for moving the organization and still lacks the motivation of managing nurses in inpatient unit so that the head nurses will be able to arouse the enthusiasm of managing nurses in providing quality service. To improve the productivity of work, effectiveness of work, success and motivation of nurses are strongly 
influenced by the implementation of the management functions of the head of the room. According to Sumiati [3], in her work at Dr. Kariadi Semarang Hospital also pointed out that the leadership of the head of the inpatient room installation mostly in the category of less as much as 63.6 percent.

Nandari [4], in research of Salatiga Hospital says that there is a positive and significant relationship between emotional intelligence with the nurses' performance, the higher the emotional intelligence of the nurse then its performance will be better. As well as, otherwise, the lower the intelligence of emotions of nurses and, so its performance is also low. Nurses who have more capabilities in reducing negative emotions and extend the positive emotions suggests higher professionalism than those who were not able to regulate emotions. The results of this study provide the implication that in the future of knowledge and emotional dimension should be included in training programs for nurses and student nurses [5]. While Umiyati [6], in his research showed that there is a positive and significant relationship between emotional intelligence with leadership effectiveness. The higher emotional intelligence leadership more effective running, and conversely the lower the intelligence of emotions, then the lower the effectiveness of his leadership. Effective leadership is a head room in the management of inpatient room which is much supported quality improvement of nursing services.

Jayapura region has six hospitals, but there are only five hospitals that we made as a place of research as follow: (1) provincial hospital in Jayapura; (2) provincial hospital in Abepura; (3) Soerdadi Soedibjo Hospital; (4) Bhayangkara Hospital; and (5) Dian Harapan Hospital. Expatriate footballers in hospitals is one of the hospitals belonging to the province of Papua which are likely to develop in meeting the needs of quality health services in the territory of Papua and the type $\mathrm{B}$ hospitals is educational hospital. The hospital has an inpatient room as much as 13 rooms are each led by a head with the educational background of the three diplomas and bachelor level. The provincial hospital is the Abepura General Hospital also belongs to the Government of Papua with the classification hospital is supported by the energy of having the average education standard of education by diploma and bachelor levels. The hospital has an inpatient room space as much as eight rooms are each led by a head with a background of diploma three and bachelor degree. Dian Harapan is a hospital belonging to the foundation, with type $\mathrm{D}$ which leads to type $\mathrm{C}$ with number of hospitalizations totaling to five, led by the head of the room with the educational background of the diploma three. Bhayangkara is a hospital belonging to the police institution, with type $\mathrm{C}$ has a hospitalization as much as five rooms, led by the head of the room with the educational background of diplomas and bachelor degree level. While Soerdadi Soedibjo is a hospital belonging to the Indonesian Navy, with type $\mathrm{C}$ has as much as five rooms, led by the head of the room with the educational background of the diplomas three degree.

Based on the results of an interview conducted in one of the nurses in Jayapura and Abepura Hospital, submit that their inpatient space management is not optimal, such as: description of tasks of the head ward has not been carried out in accordance with the standard operational procedures, the head of the room feel has yet to carry out management functions optimally inpatient space because the head of the room still to be directly involved in dealing with patients, the head of the room does not have optimum emotional intelligence where the motivation and the supervision of the head of the room is not good, and professional relations still must be improved. But the positive thing is that the policy of the hospital which is in the city of Jayapura, always pay attention to resource human development by giving the opportunity to the staff for continuing their education and trainingrelated training for improve the quality of service.

\section{Purpose}

This study aimed to know the relationship of emotional intelligence of the head room with the management of the ward in hospital areas in Jayapura city. Based on the problem above, the question of the research was "is there a relationship between emotional intelligence of the head ward with the management of the inpatient room of the hospital in Jayapura city?

\section{Methods}

This study utilized descriptive correlational design where data relating to free variables and bound variables collected in one point of time. The population in this was the head rooms in the inpatient unit hospital in Jayapura City with the total of 36 respondents. Sampling techniques in the study are total sampling techniques which were all the population becoming a sample. Even though criteria of the sample used inclusive and exclusive criteria which were the head ward present at the hospital at time and agree to be respondents. The instrument of this study used structure questioner with three points such us: (1) characteristic respondents; (2) emotional intelligence; and (3) management of inpatient room.

\section{Result}

\section{Univariate Analysis}

Univariate Analyses in this study was the management of the ward and emotional intelligence of head room. Following the distribution of head room based on with the management of the ward and emotional intelligence in the hospital area of Jayapura in 2015.

Table 1 shows that the head of the room with the management of the ward well as many as 16 nurses $(44.4 \%)$. While the head of the room who manage the ward with less space that is 20 people (55.6\%).

Table I of head room based on with the management of the ward in the hospital of Jayapura area in 2015

\begin{tabular}{lcc}
\hline $\begin{array}{l}\text { Management of Inpatient } \\
\text { Room }\end{array}$ & $\mathbf{n}$ & $\%$ \\
\hline Good & 16 & 44.4 \\
Less & 20 & 55.6 \\
\hline
\end{tabular}

\section{Note: $\mathrm{n}=36$.}

Table 2 shows that the head of the room that has high emotional intelligence capabilities in terms of self-awareness, self-control, selfmotivation, and empathy and social relations that is as many as 24 people $(66.7 \%)$. While the head of the room that has low emotional intelligence capabilities, namely 12 people (33.3\%).

Table 2 Distribution of Head Room based on emotional intelligence in the hospital of Jayapura area in 2015

\begin{tabular}{lcc}
\hline Emotional Intelligence & $\mathbf{n}$ & $\%$ \\
\hline High & 24 & 66.7 \\
Low & 12 & 33.3 \\
\hline
\end{tabular}

Submit your Article | www.ologypress.com/submit-article PP Press $f$ in $y$ ritio
Citation: Agussalim. The relationship of emotional intelligence of head room with management of the ward in hospital areas of jayapura city. Nurs Palliative Care Int. (20I8); I (I):3-9. DOI: I0.3088I/npcij.00002 


\section{Bivariate Analysis Results}

a. The relationship between emotional intelligence with management of the ward.

Relationship between the emotional intelligence head room with the management of the ward areas of the city of Jayapura in 2015 are presented in table 4 that is as follows:

Table 3 shows that head room Jayapura City hospital in 2015 have high tend emotional intelligence to manage inpatient room with good as much as 15 people $(62.5 \%)$, higher than the head of the room who manage the ward with less space by as much as nine people (37.5\%). While the head of the room that has the emotional intelligence are low, tend to manage the ward a total of 11 people with less $(91.7 \%)$.

Table 3 Analysis of the relationship between emotional intelligence Head room with with the management of the ward areas of the city of Jayapura in 2015

\begin{tabular}{|c|c|c|c|c|c|c|c|}
\hline \multirow{3}{*}{$\begin{array}{l}\text { Emotional } \\
\text { Intelligence }\end{array}$} & \multicolumn{4}{|c|}{$\begin{array}{l}\text { Management of the } \\
\text { Ward (room) }\end{array}$} & \multirow{3}{*}{ Total } & \multirow{3}{*}{$\%$} & \multirow{3}{*}{ p-value } \\
\hline & \multicolumn{2}{|c|}{ Good } & \multicolumn{2}{|c|}{ Less } & & & \\
\hline & $\mathbf{n}$ & $\%$ & $\mathbf{n}$ & $\%$ & & & \\
\hline High & 15 & 62.5 & 9 & 37.5 & 24 & 100 & \\
\hline Low & I & 8.3 & 11 & 91.7 & 12 & 100 & 0.000 \\
\hline Total & 16 & 44.4 & 20 & 55.6 & 36 & 100 & \\
\hline
\end{tabular}

Note: $n=36$; significantat $p$-value $<0.05$.

Table 4 Analysis of the relationship between the dimensions of the selfawareness of the head room with the management of the ward in hospital areas of Jayapura City in 2015

\begin{tabular}{|c|c|c|c|c|c|c|c|}
\hline \multirow{3}{*}{$\begin{array}{l}\text { Self- } \\
\text { Awareness }\end{array}$} & \multicolumn{4}{|c|}{$\begin{array}{l}\text { Management of the } \\
\text { ward (room) }\end{array}$} & \multirow{3}{*}{ Total } & \multirow{3}{*}{$\%$} & \multirow{3}{*}{ p-value } \\
\hline & \multicolumn{2}{|c|}{ Good } & \multicolumn{2}{|c|}{ Less } & & & \\
\hline & $\mathbf{n}$ & $\%$ & $n$ & $\%$ & & & \\
\hline High & 15 & 68.2 & 7 & 31.8 & 22 & 100 & 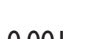 \\
\hline Low & 1 & 7.1 & 13 & 92.9 & 14 & 100 & 0.001 \\
\hline
\end{tabular}

Note: $n=36$; significant at $p$-value $<0.05$

The results of statistical tests with chi square value obtained $p=0.006$. This means there is a connection between emotional intelligence of head room with the management of the ward in hospital areas of the city of Jayapura.

a. Analysis of the relationship of self-awareness of head room with management of the ward.

Relationship between the dimensions of self-awareness with management of the ward in the hospital of Jayapura City region are presented in table 5 below:

Table 5: Analysis of the relationship between the dimensions of the head restraint with the management of spaces in hospital inpatient areas of the city of Jayapura the year 2015 .

\begin{tabular}{lllllllll}
\hline $\begin{array}{l}\text { Self- } \\
\text { control }\end{array}$ & \multicolumn{2}{l}{$\begin{array}{l}\text { Management of the } \\
\text { ward (room) }\end{array}$} & & Total & $\%$ & p-value \\
& $\mathbf{n}$ & $\%$ & $\mathbf{n}$ & $\%$ & & & \\
\hline High & 12 & 63.2 & 7 & 36.8 & 19 & 100 & \multirow{2}{*}{0.040} \\
Low & 4 & 23.5 & 13 & 76.5 & 17 & 100 & \\
\hline
\end{tabular}

Note: $\mathrm{n}=36$; significant at $\mathrm{p}$-value $<0.05$.
Table 4 shows that the head of the room in Jayapura city hospitals that have the ability of self-awareness with high tend to manage good ward as much as 15 people (68.2\%), higher than the head of the room who manage the ward with less by as much as seven people (31.8\%). While the head of the room that has self-awareness are low tend to manage room with less as many as 13 people $(92.9 \%)$.

The results of statistical tests with chi square value obtained $\mathrm{p}=$ 0.001 . This means there is a connection between dimensions of selfawareness with head room management in hospital areas of Jayapura city.

\section{b. Analysis of the relationship control head with inpatient space management}

Relationship between the dimensions of the head restraint with the management of spaces in hospital inpatient Jayapura Region are presented in table 6 that is as follows:

Table 6 Analysis of the relationship between the dimensions of self-motivation with head room management in hospital areas of Jayapura city in 2015

\begin{tabular}{|c|c|c|c|c|c|c|c|}
\hline \multirow{3}{*}{$\begin{array}{l}\text { Self- } \\
\text { Motivation }\end{array}$} & \multicolumn{4}{|c|}{$\begin{array}{l}\text { Management of the } \\
\text { ward (room) }\end{array}$} & \multirow{3}{*}{ Total } & \multirow{3}{*}{$\%$} & \multirow{3}{*}{ p-value } \\
\hline & \multicolumn{2}{|c|}{ Good } & \multicolumn{2}{|c|}{ Less } & & & \\
\hline & $\mathbf{n}$ & $\%$ & $\mathbf{n}$ & $\%$ & & & \\
\hline High & II & 68.8 & 5 & 31.2 & 16 & 100 & \\
\hline Low & 5 & 25.0 & 15 & 75.0 & 20 & 100 & 0.022 \\
\hline
\end{tabular}

Note: $\mathrm{n}=36$; significant at $\mathrm{p}$-value $<0.05$.

Table 5 shows that head room in the hospitals of jayapura city that have the ability of controlling ourselves with high tend to manage the room well as many as 12 people (63.2\%), higher than the head of the room who manage inpatient with less by as much as seven people $(36.8 \%)$. While the head of the room that has the control of us are low tend to manage the room with less as much as 13 people $(76.5 \%)$.

The results of statistical tests with chi square value obtained $\mathrm{p}=$ 0.040 . This means there is a connection between the dimensions of the head restraint with the management of the ward in hospital areas of Jayapura City.

c. Analysis of the relationship motivation of head room with management of the ward.

Relationship between the dimensions of self-motivation of head room with management of the ward in a hospital of Jayapura City region are presented in table 7 , namely as follows:

Table 7: Analysis of the relationship between the dimensions of empathy with head room management in hospital areas of the city of Jayapura in 2015.

\begin{tabular}{|c|c|c|c|c|c|c|c|}
\hline \multirow{3}{*}{ Empathy } & \multicolumn{4}{|c|}{$\begin{array}{l}\text { Management of the } \\
\text { ward (room) }\end{array}$} & \multirow{3}{*}{ Total } & \multirow{3}{*}{$\%$} & \multirow{3}{*}{ p-value } \\
\hline & \multicolumn{2}{|c|}{ Good } & \multicolumn{2}{|c|}{ Less } & & & \\
\hline & $\mathbf{n}$ & $\%$ & $\mathbf{n}$ & $\%$ & & & \\
\hline High & 14 & 70.0 & 6 & 30.0 & 20 & 100 & 00 \\
\hline Low & 2 & 12.5 & 14 & 87.5 & 16 & 100 & 0.002 \\
\hline
\end{tabular}

Note: $\mathrm{n}=36$; significant at $\mathrm{p}$-value $<0.05$.

Table 6 indicates that the head of the room of the hospital in Jayapura city area that have the ability of high self-motivation to tend to manage the room with either a total of 11 people $(68.8 \%)$, higher than the head 
of the room who manage the room with less space by as much as five people $(31.2 \%)$. While the head of the room that has a self-motivation are low to tend to manage of the clients staying is less as much as 15 people $(75.0 \%)$.

The results of statistical tests with chi square value obtained $\mathrm{p}=$ 0.022 . This means there is a connection between the dimensions of self-motivation with head room management in hospital areas of the city of Jayapura.

\section{d. Analysis of the relationship of empathy of head of the room with the management of room}

Relationship between the dimensions of empathy with head room management of care in a hospital in Jayapura City region are presented in table 8 as follows:

Table 8 Analysis of the relationship between the dimensions of socia relations of head room with the management of the room in hospital area of the city of Jayapura in 2015

\begin{tabular}{|c|c|c|c|c|c|c|c|}
\hline \multirow{3}{*}{$\begin{array}{l}\text { Social } \\
\text { Relations }\end{array}$} & \multicolumn{4}{|c|}{$\begin{array}{l}\text { Management of } \\
\text { Inpatient Room }\end{array}$} & \multirow{3}{*}{ Total } & \multirow{3}{*}{$\%$} & \multirow{3}{*}{ p-value } \\
\hline & \multicolumn{2}{|c|}{ Good } & \multicolumn{2}{|c|}{ Less } & & & \\
\hline & $\mathbf{n}$ & $\%$ & $n$ & $\%$ & & & \\
\hline High & 13 & 72.2 & 5 & 27.8 & 18 & 100 & \\
\hline Low & 3 & 16.7 & 15 & 83.3 & 18 & 100 & \\
\hline
\end{tabular}

Note: $n=36$; significant at $p$-value $<0.05$.

Table 7 shows that head room of the hospital in Jayapura City Area have the ability of high empathy to tend to manage the room well as much as 14 people $(70.0 \%)$, higher than the head of the room who manage client's room less as six people $(30.0 \%)$. While the head of the room that has low empathy tend to manage clients room less as many as 14 people $(87.5 \%)$.

The results of statistical tests with chi square $p=0.002$ value obtained $(p<0.05)$. This means there is a connection between dimensions of empathy with head room management in hospital areas of the city of Jayapura.

\section{e. Analysis of the relationship between social relationship of head room with the management of the ward.}

Relationship between the dimension of social relations of head room with room management care of in hospital area of Jayapura City are presented in table 8 as follows:

Table 7 shows that head room of the hospital of Jayapura City Area have the ability in doing social relations highly to manage the good room as much as 13 people (72.2\%), higher than the head of the room who manage the room with less two persons $(12.5 \%)$. While the head of the room that has the capability of doing social relations are low to manage the room with less as much as 15 people $(83.3 \%)$.

The results of statistical tests with chi square value obtained $\mathrm{p}=$ 0.003 . This means there is a connection between dimension of social relations with the management of the room in hospital areas of the city of Jayapura.

\section{Discussion}

Analysis of the relationship between emotional intelligence of the head with the management of the ward.

Emotional intelligence according to Chaplin [7] in Notoadmodjo is the ability to recognize emotions themselves, the ability to manage emotions, ability to motivate themselves, the ability to recognize emotions of others (empathy) and ability to foster social relations. This is a very emotional intelligence affect of persons' life overall ranging from life in a family, a job, and interaction with the social environment.

Goleman [8] States that the success of one is just determined by the $20 \%$ of the level of intellectual intelligence (IQ), while 80 percent is determined by other factors, including emotional intelligence (EQ). People with well-developed emotional intelligence means will be happy and successful in life and master the habits of mind that encourages their productivity [8].

Emotional intelligence is very needed by head room for nurses who are always in touch with patients that cultural background and its nature is different. In addition to the need to have the attitude of painstaking and attentive, the head of the room are always willing to help with gusto, and then also required a willingness to always follow all that has to do with the issue of health care generally. A head of a room that does not have a high emotional intelligence can be characterized by an attitude of high emotion, quickly act on his emotions, and insensitive with the feelings and conditions of others [8].

The results showed that the head of the room in Jayapura City Hospital in 2015 have high tend of emotional intelligence to manage the client's room with good as much as 15 people $(62.5 \%)$, higher than the head of the room who manage clients' room with less space by as much as nine people (37.5\%). While the head of the room that has the emotional intelligence are low percentage to manage client's room in less 11 people $(91.7 \%)$. This indicates a diversity level of emotional intelligence on the head room in the basement of the ward of Hospital area of Jayapura in 2015. Diversity levels of emotional intelligence head of the room can be caused by many factors. In theory, the factors that affect emotional intelligence that is the innate nature of genetic factors and environmental factors. Mayer Goleman [8] expressed the opinion that emotional intelligence is evolving in line with age and experience from childhood to adulthood. It means that the levels of emotional intelligence are strongly influenced by the age and life experience. Based on the results of the statistical test value obtained with $\mathrm{p}-0.06$. This means there is a connection between emotional intelligence of head room with management of the ward in hospital areas of the city of Jayapura.

Experience of life from childhood until adulthood every individual nurse is very diverse. The experience gained from the environment will affect the individual's emotional intelligence. Pleasant experience will provide a positive influence against individuals, but the experience is unpleasant when it is always repeating itself which can give negative effects towards the maturity of individual emotions. The characteristics of the age of majority of the respondents are 30 to 49 years as many as 31 people $(86.1 \%)$. It can be concluded the age 
of respondents that the majority belongs to the age of majority until his emotional intelligence level is still in the development stage, as intelligence emotions evolved in line with the increase of age. This is in accordance with the results of the study, [9] that older people may be higher in emotional intelligence, this discovery shows emotional intelligence is the ability to develop, it is likely that the accumulated life experiences contribute to the emotional intelligence [9].

In addition to age, educational factors can also affect the rate of emotional intelligence, educational characteristics of respondents. The majority of educated undergraduate nursing is as many as 19 people $(52.78 \%)$. With undergraduate education tends to be a higher level of education compared to his emotional intelligence of Diplomas level. This is in line with the results of the research of Tukijan \& Harnoto which suggests that the level of education affects to the emotional intelligence. In other words, there is a difference between emotional intelligence education DIII with undergraduate education (Tukijan \& Harnoto). This can be caused by increasing the level of education of the head of the room then it will be more and more experiences even insights gained by the head of the room during lectures either pleasant or bad that would have an impact in the way think, behave or how to behave, so that the adjustment can be seen and his experience in the world of work. Education can be one of the means of individual learning to develop emotional intelligence. Individual start introduced various forms of emotions and how to manage it [10].

Martin [11] stated that emotional maturity cannot happen in an instant through coercion for example by following the Flash courses. This process can only be facilitated by the operations, but it cannot be forced. The job as the head of the room in managing room is needed the ability to recognize emotions, ability to manage emotions, ability to motivate themselves, the ability to recognize other people's emotions and ability to build relationships with others. So it will be a mutual relationship of mutual trust and mutual help between the head of the room with the patient, the head of the room with the family, the head of the room with the doctor, the head of the room with other health team. Martin [11] declared workers relating to a lot of people and apply emotional intelligence in the job proved to be more successful. They are more empathetic, communicative, humorous, and more sensitive to the needs of others.

The results of the research and explanation above confirm that the head of the room needs to have a high emotional intelligence in their daily work. Therefore, the head of the room in the hospital area of Jayapura need to intervene in order for developing emotional intelligence abilities on the nurses covering aspects of self-awareness, self-management, social awareness, management of social relations in the framework of the management room.

Analysis of the relationship between the dimensions of the self-awareness of the head with the management of inpatient ward.

Emotional awareness is the ability to recognize emotions at the time happened. Awareness of emotion means beware of mood or mind about mood or not drift into emotions. People who can recognize emotion or self-awareness towards emotions, not blind to his own, including their emotional can give a label every emotion felt appropriately. Recognize the emotion or self-awareness against this emotion is the basis of emotional intelligence. [12].
From the results of research conducted that head room in the hospital area of Jayapura that had the high tend capability of self-awareness to manage inpatient room well as many as 15 people (68.2\%), higher than the head of the room who manage the ward less as much as seven people $(31.8 \%)$. While the head of the room that has self-awareness are low tend to manage the room with less as many as 13 people $(92.9 \%)$. This is in accordance with the opinion of the experts that the person who has the consciousness of emotion will be able to undertake the management of the ward with good result.

Head room that has emotional consciousness aware what we're thinking and what will we feel at this time. Self-awareness towards emotion emotional intelligence is a coronal. If we want to develop emotional intelligence, we should start by increasing self-awareness.

Based on the research that is conducted at the head of the room in Jayapura City Hospital in 2015 shows no relationship between the dimensions of self-awareness with head room management in hospital areas of the city of Jayapura in 2015. It can be seen from the p-value $=0.001$ which means a high sense of self can be a relationship that management of inpatient room would be good.

Emotional Awareness is associated with management of inpatient room in the ward unit in Jayapura city area hospital This is in accordance with previous theory advanced by Goleman [8] the emotion of that awareness is the ability to recognize emotions at the time it happened. Awareness of emotion means beware of mood or mind about mood or not drift into emotions. People who can recognize emotion or self-awareness towards emotions, not blind to his own, including their emotional can give a label every emotion felt appropriately. Recognize the emotion or self awareness against this emotion is the basis of emotional intelligence. Emotions give information if ignored will result in serious problems. If we are aware of the existence of these emotions, then we will treat these emotions with rational, so that someone will be able to perform the ward management properly. Lack of awareness about aspects of you will influence in the management of inpatient room. Increased self-awareness will result in the management of the patient with good care.

Unbalanced relationship can give rise to the tension of emotions. Emotions play a role is important because the emotion help the realization of self in touch, either in personal, with other people and the environment.

\section{Analysis of the relationship between the dimensions of self- control with the management of ward.}

The second emotional intelligence factors such us controlling emotions have an effect against of room management. People are able to control our emotions, stay calm, and think positive and unconfused even during very difficult circumstances. They are able to manage emotions that are relax and reduce anxiety at the moment of experiencing the emotions as well as steady; calm thinking (i.e. remains focused despite being under pressure though). A state of calm and stable it makes a person can perform management of care with others. Unlike the difficult people in control of themselves, then they will do the obstacles in the management of inpatient room. [12].

According to the assumptions of the researcher that the interns of the management of inpatient care to achieve the goal of managing inpatient care which needed controlled themselves. Controlled yourself in the 
management of inpatient room is the ability of overcoming emotions and giving priority to the implementation of more tasks than putting forward your emotions. It will make it easier got the expected goal when this function is not done then the nursing goal would not be achieved. In terms of ward management of inpatient care in a hospital area of Jayapura that is acting the head of the room.

From the results of research conducted that head room of the hospital in Jayapura City that have the high tend ability of controlling ourselves to manage inpatient room well as many as 12 people $(63.2 \%)$, higher than the head of the room who manage inpatient with less by as much as seven people (36.8\%). While the head of the room that has the control of us are low tend to manage space inpatient with less as many as 13 people (76.5\%). On this cross-tabulations may note that head room who has the control of low emotions will conduct the management of inpatient room which is lacking and the head of the room which has control of high emotion will do management of good inpatient room.

This is in accordance with previous theory who said that the factors controlling emotion is a factor related to the management of inpatient room. [12].

Based on the research that the head of the room in Jayapura City hospitals in 2015 shows there is relationship between the the dimensions of the head restraint with the management of spaces of inpatient care in a hospital in Jayapura City region can be viewed from the $p$-value $=0.04$ which means high self-control can affect the good management of the inpatient room.

This is in line with the research of Maria Jose et al. [13] that the variable dimension of self-control head executor room p-value 0.001 and shows self-control head room has an impact on the management of inpatient room. Inpatient room management is done by the head of the room has been managing inpatient room nicely by giving a model for controlling emotions. In interaction with the patient, the head of the room sometimes dealing with the patient, maybe even threats from the patient.

\section{Analysis of the relationship between the dimensions of self- motivation with the management of inpatient room.}

The ability to survive and continuously trying to find as many ways for the sake of achieving the objective. The characteristics of individuals who have this ability is to have high confidence, optimists in the difficult circumstances of care, quite skilled and flexible in finding alternative ways of enabling objectives achieved, and quite capable of solving tasks the weight of a small easy tasks being executed. Individuals who have these skills tend to be much more productive and effective in terms of whatever they're working on. [14].

From the results of research conducted that head room area hospital of Jayapura City have the ability of high tend of self-motivation to manage inpatient room with either a total of 11 people $(68.8 \%)$, higher than the head of the room who manage inpatient with less space by as much as five people $(31.2 \%)$. While the head of the room that has a self-motivation are low tend to manage space to stay with less as much as 15 people $(75.0 \%)$.

Moekijat [15] stated that the willingness of someone to do a job can be affected by factors that are coming from outside or from inside as delivered by Herzberg Motivation Theory. There are two types of factors encourage someone to try to reach a contentment and distance themselves from the insurrection. Two factors that he called hygiene factors (extrinsic factor) and intrinsic factor. Hygiene factors motivate someone to get out of dissatisfaction, including supervision and administration, policy, working conditions, human relationships, reward, environmental conditions, and security (extrinsic factor), whereas factor motivator of someone to attempt to reach a contentment, which included therein is the accomplishment/ achievement, recognition, work that is challenging, increased responsibilities and advancement level of life.

In the results of this research are known to most head room that shows the management of inpatient rooms are those who have the motivation to meet the needs for achievement, it is appropriate to the characteristics of respondents which are head room show that most head room that became respondents. They have worked for five years is as many as 33 people (86.84\%). Based on research conducted at the head of the Region's hospital room in Jayapura showed no relationship between the dimensions of self-motivation head room with space management of inpatient care in a hospital in Jayapura City region in 2015 can be viewed from the value $\mathrm{p}=0.022$.

This is in line with research conducted by Cadman \& Brewe [16] shows that the variable self-motivation a high head with $p$-value 0.016 and Ext B 6.238 has an impact on the management of inpatient room bigger comparison of head room that has low self-motivation. In this study, the variable motivation focused on the behavior of people who were motivated, where the charge indicators were as follows: (1) focus, someone has good motivation when you know your goal and what to do; (2) intensity, someone has good motivation when you have the hard effort and a willingness to try; (3) quality, someone has good motivation when you know how to/strategies/procedures for doing so; and, (4) duration, someone has good motivations as seen from how long he used the time for effective work.

\section{Analysis of the relationship between the dimensions of empathy with the management of inpatient room.}

The ability to recognize the emotions of other people is also called empathy. A person's ability to recognize others or care shows the capabilities of one's empathy. Individual that has the ability of empathy is more able to capture signals the hidden social signaling anything needed other people so he better able to accept the other person's point of view, be sensitive to the feelings of others and more being able to listen to others.

Rogers said that in the face of a patient who suffered emotional disorders needed empathy attitude of nurses, a nurse must be able to reflect that is able to understand the basis of empathy into inpatient space management. Based on the results of the research the head room Jayapura City hospital in 2015, suggesting that the head room in the hospital area of Jayapura have the ability of empathy with high tend to Manage inpatient room with good as much as $14(70.0 \%)$, higher than the head of the room who manage inpatient space with less as six people $(30.0 \%)$. While the head of the room that has low empathy tend to manage inpatient with less care as many as 14 people (87.5\%). The ability of head room to develop others, grow through association as well as understanding the emotions of a group is a good potential. Development staff program can cultivate empathy, orientation services, and the management of the hospital.

Based on research conducted at the head of the Region's hospital room in Jayapura showed relationship between dimensions of empathy with head management of inpatient care in a hospital of Jayapura City region which can be viewed from the $\mathrm{p}$-value $=0.002$. 
This is in line with the research Fernandez-Berrocal, et al. [17] shows the head of a room that has a high perceived empathy ability better manage inpatient space compared to the head of the room that has the ability of empathy. Further analysis showed that the head of the room that has the ability of empathy within 2.56 times are perceived better in managing the room. Individuals who are able to understand and support the emotions of other people will be better able to understand the feelings, thoughts, and the situation is perceived by others, are able to understand the perspectives of others, fosters mutual trust and align themselves with other people [8]. With empathy to nurse, then the head of the room will be more able to show gratitude towards nurses and health teams in every decision and action which is an aspect in the management of inpatient room.

According to the assumptions of the researcher that making good relationship with someone will be making someone open to reveal himself, the more carefully its perception of others and the perception of him. Capable of handling the emotions of other people is the core of fostering relationships with others.

\section{Analysis of the relationship between the dimensions of social relations with the management of inpatient ward.}

Fostering relationships with others (social skills) is not only tangible in the form of interaction with others, but also capable of influencing and leading the discussion and resolving disputes, and for working together and work in teams.

Social relationships are very great benefit for someone who is having problems, especially social relations that comes from a man who has very deep emotional bonds, people close, best friend, a very trusted or a very love man. Social relationships can be given an impetus to rekindle the passion in the face of challenges, and demonstrated to him that there are still other people who care. Environmental factors can shape social relations which is including conform to the patient, to interact smoothly and avoid splits or disputes among my colleagues. With the social relationships that are high then individuals can better get the job which is done in terms of management.

Based on the results of the research conducted that the head room in the hospital area of Jayapura have the ability in conducting social relations which are high tend to Manage inpatient room with good as much as 13 people $(72.2 \%)$, higher than the head of the room who manage inpatient space with less two people $(12.5 \%)$. While the head of the room that has the capability of doing social relations are low tend to manage inpatient with less care by as much as 15 people $(83.3 \%)$

Based on research conducted at the head of the Region's hospital room in Jayapura showed no relationship between dimension of social relations of head room with space management of inpatient care in a hospital in Jayapura City region which can views of the $\mathrm{p}$-value= 0.003 .

This is in line with research conducted by Salovey \& Mayer [18] shows the influence of variable room management towards social relationships in the Inpatient Unit shown in (B): 3.934, p-value= 0.001 . Based on the results can be concluded that there is a significant influence on social relations with the management of inpatient room of the head room. The head room has low social relationship management room hospitalization 3.934 lower than at the head of the room which had high social relationships. The head of the room which had a high social relationship management room hospitalization 3.934 higher than nurses who had low social relationships. Research results above correspond to the previous theory that social relations will determine the effectiveness of the management of the inpatient rooms. People who have high social relationships will have a high confidence level. This belief is improving the management of inpatient room because it will be easier in terms of interaction with nurses and other health care team. [19].

With this Foundation, the skill of dealing with others will become mature. The ability of someone like this allows one to establish a relationship to move and inspire others, fostering a proximity relationship, convince, influence and make other people feel comfortable.

\section{References}

1. Huber DL. Leadership \& Nursing Care Management ( $3^{\text {rd }}$ edition). Philadelphia: Saunders Elsevier. (2006).

2. Sitorus R. Manajemen Keperawatan di Ruang Rawat, Jakarta; Sagung Seto. (2011).

3. Sumiati A. Analisi Faktor-Faktor Yang Berhubungan Dengan Kinerja Kepala Ruang Rawat Inap di rumah sakit Dr. Kariadi Semarang. (2006).

4. Nandari, Kusuma. Hubungan Kecerdasan Emosi Dengan Kinerja Perawat Rumah Sakit Umum Daerah Kota Salatiga. (2012).

5. Landa A, Zafra E. The Impact of Emotional Intelligence on Nursing: An Overview. (2010).

6. Umiyati. Hubungan Antara Kecerdasan Emosi dengan Efektifitas kepemimpinan. (2006).

7. Notoatmodjo S. Metodologi Penelitian Kesehatan, Penerbit Rineka Cipta Jakarta. (2010).

8. Goleman. Emotional Intelligence PT. Gramedia Pustaka Utama, Jakarta. (2004).

9. Fariselli L, Ghini M, Freedman J. Age and Emotional Intelligence. (2006).

10. Agustian AG. Rahasia sukses membangun kecerdasan emosi dan spiritual: Emotional spiritual quotient berdasarkan 6 Rukun Iman dan 5 Rukun Islam. Jakarta: by Arya. (2010).

11. Martin AD. Emotional Quality Management, Arga, Jakarta. (2013).

12. Shapiro LE. Mengajarkan Intelligence Pada Anak. Jakarta; PT. Gramedia Pustaka utama. (2013).

13. Maria Jose, Esther López-Zafra. The Impact of Emotional Intelligence on Nursing: An Overview. Psychology. (2010);1:50-58.

14. Mulyani S. Analisis Faktor-Faktor Kecerdasan Emosi Terhadap Komunikasi Interpersonal Perawat Dengan Pasien Di Unit Rawat Inap RSUD Dr. Amino Gondo Hutomo Semarang. (2008).

15. Moekijat. Teori Komunikasi. Mandar Maju; Bandung. (2002).

16. Cadman A, Brewer J. Emotional Intelligence: A Vital Prerequisite for Recruitment in Nursing. Journal of Nursing Management. (2011);9:321-324.

17. Fernandez-Berrocal, Rocio Alcaide, Natalio Extremera. The Role of Emotional Intelligence in Anxiety and Depression among Adolescents. Individual Differences Research. (2013);4(1):16-27.

18. Salovey, Mayer JD. Emotional Intelligence, Imagination, Cognition and Personality. Australian Journal of Advanced Nursing. (2007);24(3):60-64.

19. Ellis RB. Pengelolaan Ruangan Rawat Inap: Teori dan Praktik. Buku Kedokteran EGC, Jakarta. (2010). 